\title{
Economic Integration vs. Conflicts in Northeast Asia - A Role of Confucianism
}

\author{
Heeho Kim ${ }^{1} \&$ Byeong-hae Sohn ${ }^{2}$ \\ ${ }^{1}$ Department of Economics, Kyungpook National University, Republic of Korea \\ ${ }^{2}$ School of Economics and International Trade, Kyungpook National University, Republic of Korea \\ Correspondence: Heeho Kim, Department of Economics, Kyungpook National University, Republic of Korea. \\ E-mail: kimhh@knu.ac.kr
}

Received: April 13, 2014 Accepted: May 21, 2014 Online Published: June 25, 2014

doi:10.5539/ass.v10n13p155 URL: http://dx.doi.org/10.5539/ass.v10n13p155

\begin{abstract}
This study has examined the culture commonality of Northeast Asian countries based on Confucian values, and their relations to institutional economic integration. This study demonstrates that Confucian values inherent in the Northeast Asian countries have served as the cultural ethos for the rapid economic growth of this region since the 1960s and will be able to form the foundation of Northeast Asian values in the future. This paper re-appreciates these cultural values as a necessary condition for regional integration to catalyze the stagnated discussions about economic integration and extends its inter-weaving connection role for intra-regional transaction among China, Japan and Korea.
\end{abstract}

Keywords: confucianism, Northeast Asia, economic integration, economic growth, conflicts

\section{Introduction}

In the process of modernization during the $20^{\text {th }}$ century, the Northeast Asian countries such as China, Japan and Korea (C.J.K) have passed through a harsh history of colonization, military invasion, ideological confrontations, and national division by ideological war. These historical experiences make the Northeast Asian countries find it hard to shake off their strong nationalism, despite the growing regionalism elsewhere. These historical remnants have prevented C.J.K. from laying a credible foundation for political and economic cooperation in this region and have made it difficult to establish an institutional economic community although intra-regional trade within Northeast Asia is rapidly increasing. Institutional Economic Integration is to set up an integrated economic community among the specific country members by eliminating all kinds of tariff and non-tariff barriers to free trade and economic activities between themselves. One of main types of the institutional economic integration is Free Trade Agreement (FTA) which eliminates all internal tariff barriers to free trade between the member countries within a region.

The rapid economic growth of China since the 1990s has led to increasing economic interdependency among Northeast Asian countries, and consequently a market led functional economic integration has been developing in this region. The statistical analysis in the section 4 shows that there was a growing tendency of functional economic integration and the increasing intra-regional trades among China, Japan and Korea (C.J.K) during the last decades. A region-wide institutional integration scheme is required to expand a degree of this functional integration, and continues to discuss on building a Northeast Asian economic community (Note 1) since the 1990s.

In spite of the functional necessity for institutional integration of the Northeast Asia, no inter-governmental integration agreement has yet been concluded due to the emotional barrier of mutual distrust resulting from historical conflicts. This emotional distrust among neighboring countries is so hard to eliminate that it needs to develop common regional identity and common values based on cultural commonality as necessary condition for the institutional integration. Nevertheless, the discussion on institutional economic integration led by C.J.K has focused mainly on enhancing economic interests rather than on recognizing culture commonality. Most sociologist and economists have tended to overlook socio-cultural factors in analyzing regional integration issues because they are implicit, invisible and immeasurable. 
C.J.K shared common values as a "Northeast Asian cultural community" based on Chinese Confucianism, Buddhism, and Taoism until the $19^{\text {th }}$ century. It was not until the end of the $19^{\text {th }}$ century that such common cultures began to disintegrate and pass into history with the intrusion of Western civilization and the invasions of Japan into China and Korea. Therefore, the re-appreciation of such inherent common cultures would facilitate a new potential for building institutional economic integration in Northeast Asia.

This paper is a first attempt to shed light on the values and roles of the Confucian culture as cultural commonality in newly building up institutional integration among C.J.K. Buddhism and Taoism as well as Confucianism underlie as cultural commonality in Northeast Asia. Buddhism, however, is based on non-political teachings and deals with life beyond death and religious spiritualism, while Taoism is based on a monastic ideology sequestered from the world. Meanwhile, Confucianism was one of the first offshoots of literati culture and has dominated Chinese culture for two and a half millennia. Confucian philosophy has more widespread and profound roots within Northeast Asian region (Note 2). Confucianism has played a leading role as a political ideology and a socio-economic norm in influencing people's daily lives. (Yang, 2000). Therefore, Confucian values will be examined as the most important traditional cultural commonality in this region to discuss institutional economic integration. Although among the East Asian countries with Confucian culture are Hong Kong, Taiwan, Macao, Vietnam and Singapore as well as China, Korea and Japan, we will focus on the institutional integration between the latter three countries, C.J.K. It is because these three countries play central roles in economic activities of East Asia, and because Hong Kong, Taiwan, Macao, and Singapore belong historically and demographically to territorial scope of China. Japan still has a part of Confucian culture in its social and educational system and values even though it tried to be de-Asianized since the Meiji period of the 19th century.

Section 2 of this paper analyzes the historical experiences of Confucianism and traditional cultures in the Northeast Asia, and compares it with the role of Christian culture as a cultural commonality in the European Union. Section 3 explains the values of Confucianism in an economic perspective, and Section 4 examines the economic integration and conflicts among the Northeast Asian countries. Section 5 analyzes the roles of Confucian culture as cultural commonality for an institutional integration among the Northeast Asian countries. The last section provides the expected vision and policy implications for the regional economic integration based on Confucian culture as cultural commonality in this region. The associated negative issues with the Confucian values on the regional integration are discussed.

\section{Traditional Cultures and Confucianism in the Northeast Asia}

\subsection{Traditional Cultures and Confucianism}

From a historical perspective, China, Japan and Korea belong to the "East Asian cultural community," sharing common Chinese cultural factors: Confucianism, Chinese characters, code of laws, Chinese sciences (the Yin-Yang philosophy, astronomy, and Chinese medicine) and Chinese Buddhism. Those cultural factors began to appear among the East Asian countries (actually it refers to Northeast Asian region but in historical concept it refers to East Asia) since the 8th century, the era of the Tang dynasty in China. China, Manchuria, Korea, and Japan since then have got integrated into a Chinese-oriented cultural community by a "Recognition system of peripheral political regime by Chinese empire" (冊封制度) and “Tribute system” (朝貢貿易). (Wada, 2003; Goyasu, 2005). This "East Asian cultural community" lasted for more than 1,000 years, and historically shared a cultural identity among the East Asian countries before this cultural community was disintegrated by invasion of Western cultures in the 19th century. East Asia was regarded as one community in terms of culture and civilization, and as a unique world sharing common (Chinese) cultural values. It distinctively differentiated itself not only from the Western and the Islamic world, but also from other Asian countries such as India. The discussion of institutional (economic) integration in the East Asia is necessary to recall the cultural commonality shared among this region until the end of the 19th century.

Among the common cultural factors of the "East Asian cultural community", Chinese Buddhism contributed to the stable life of the people through praying to Buddha for mercy and for afterlife. Buddhism could not directly influence the political and economic system of the traditional society in the East Asia. Chinese character, Chinese medicine, and the Yin-Yang philosophy have been channeled into people's life mainly through Confucianism. Confucianism was introduced as a means of spreading the political ideology of the ruling classes over people, and as an ethical norm for people's daily life. In this way, social norms and political ideology were largely set up by Confucian values, although their civic life varied among the nations. This historical common cultural community based on Confucianism serves to form a regional common identity and common values as a necessary condition to consolidate the Northeast Asian countries into a single economic community. 
Figure 1 compares the Confucian culture (distance) index for China, Japan and Korea. The Confucian (distance) index are 118 for China, 80 for Japan and 75 for Korea, all of which are higher than those index of the other Asian countries and the EU and the U.S. Malaysian Index is very low because it has Islam culture. The cultural (distance) index can be interpreted as dealing with society's search for virtue of Confucian culture, and are obtained from the Hofstede center for cultural distance. (Note 3)

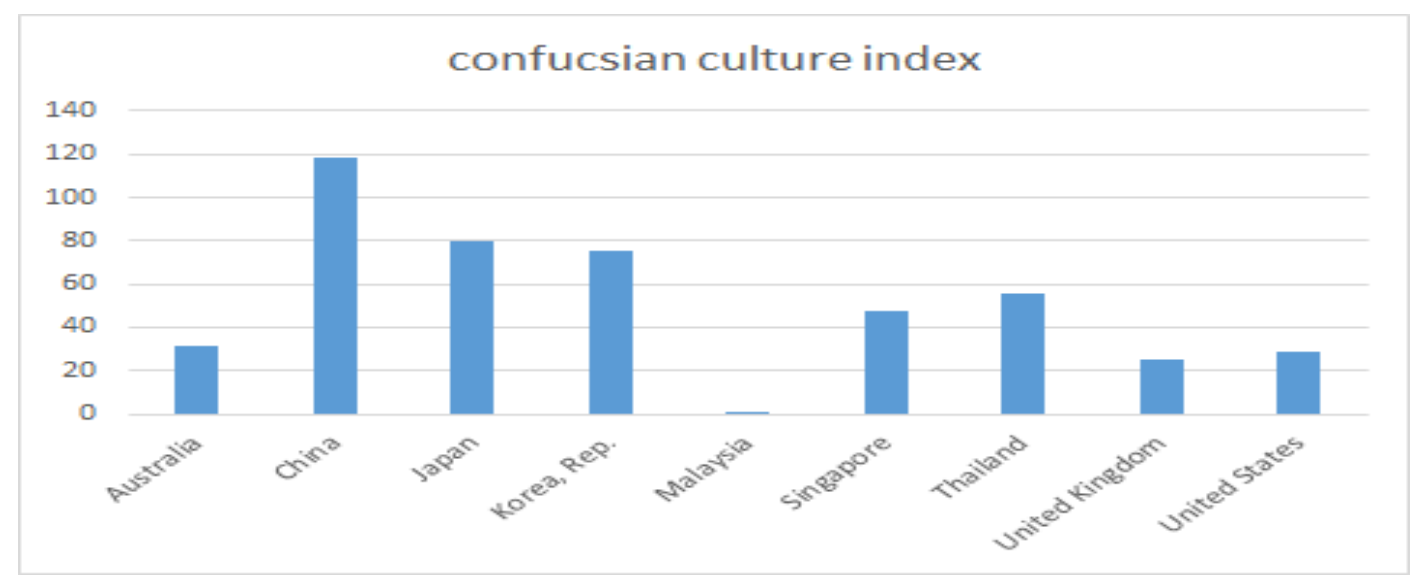

*source: Hofstede center for cultural distance (http://geert-hofstede.com/)

Figure 1. Confucian culture index

"Northeast Asian cultural community" based on Chinese Culture gradually disappeared along with the intrusion of Western civilization and the invasions and colonization by Japan into China and Korea in the early 20th century. It is in the mid $20^{\text {th }}$ century when the Chinese communist party criticized traditional cultures and Confucianism as being evil, lazy and unproductive during the period of "Cultural Revolution" in China. Thus, regional cultural community and the role of Confucian culture was not recognized in discussion of the Northeast Asian regional economic integration anymore ever since 1990s. A recent survey study by $\mathrm{Na}$, et al (2009) shows that the cultural commonality representing Confucianism is still recognized by more than $90 \%$ people in China, Japan and Korea, although its traditional patterns and characteristics are much distorted.

\subsection{Confucianism as a Source of Common Regional Value}

How significant are such Confucian values in the discussion on a set-up of C.J.K institutional economic integration? This question can be answered by looking at the cultural requirements as a necessary condition for institutional economic integration. The necessary condition of culture for economic integration requires the existence of cultural similarity among member countries from which a source of common regional value can be found. Regional common values derived from cultural commonality can act as a central force to consolidate the member countries into an integrated economic community. As shown before, Confucianism provides a cultural commonality for C.J.K., which is able to create common regional values, "so-called" Northeast Asian values, derived from Confucian values.

According to Sohn (2012b) and Na, et al (2009), "Northeast Asian value" (Note 4) in this paper is defined as a kind of thought-way or common cultural and social consciousness that promote mutual cooperation and banding together among Northeast Asian countries. Using this definition, the essential values of Confucianism can be drawn to represent a basic thought of Northeast Asian values. Confucianism is not a religion but rather schools of philosophy and knowledge system. Chinese orthodox Confucianism as a knowledge system has been transformed into various types of thought-way from the fundamental Confucianism at its early stage to the Neo Confucianism movement at modern times.

Despite the evolution of the thoughts of Confucian school, the fundamental and conceptual thought of Confucianism remains to be "Ren (仁): Humanity and Benevolence". The main stream of traditional Confucian values such as morality-based political ideology (德治), virtue of loyalty and filial piety has its origin in the notion of "Ren". "Ren" means humanity and benevolence as a foremost fundamental value of Confucianism. "Ren" is the ideal level of self-mind cultivation, indicating "love others and practice moral virtue (德)". Meanwhile, "Ren" translates into "filial piety" (孝) when applied to parents, "fraternity" (悌) when applied to 
siblings and "trust" (信) when applied to friends. "Ren" also means "loyalty" (忠) when practiced through devotion to others, to society and to the nation. The concept of "Ren" served to strengthen family ties through "filial piety" and "fraternity" and served to maintain social and national solidarity through "loyalty". Furthermore, it underlay the political concept of "moral governance" through the principle of "politics for the people".

Some aspects of Confucianism such as temperate living of common people were so emphasized that they became distorted into an ineffective social norm. The over-emphasis on loyalty, filial piety and submission to the ruling classes make Confucianism be sometimes considered as an ideology justifying the reign of the ruling classes over the people. However, the ideal goal of the orthodox Confucianism is to establish a nation where the "for-the-people" ideology can be realized by means of "Ren" and the morality principles of politics. These political ideology allows the people to remain loyal to the ruler and nation and to be respectful to the Confucian scholars, while the ruling classes take good care of the people and government official served the people as public servants. These political philosophy and morality social norm maintain traditional Confucian society as its stable social order for a long history.

Confucianism in the Northeast Asia developed a sense of familial, social and national solidarity, as well as a collective mind in which self-interest was preceded by public interest. Thus, the Confucian cultural characteristics of Northeast Asian traditional society, representing morality-based political philosophy, were the "Northeast Asian value". These Asian cultural characteristics contrast to the Western individualism and political doctrines based on a legal standard. C.J.K. easily share common Confucian values to some extent despite their different processes of modernization and their historical experiences, which is the most important condition for the institutional economic integration in Northeast Asia.

\subsection{A case Study on a Role of Christian Culture in European Union}

European Union (EU) has characteristics of "Gemeinschaft" in Europe, and institutional integration among European countries, which share geographical and cultural community among them. EU is developed to cope with the political threatening of Eastern Europe during the Cold War and with economic re-construction after the world war II. However, most development of EU is attributable to common cultural identity based on Christianity in its long history. (Note 5) European common identity began from territorial struggles against countries located in Iberia peninsular, and from the Crusade war against Islam countries between the $11^{\text {th }}$ through $13^{\text {th }}$ century. European common identity was formed from these two historical events, and Pope became an representative emblem of world Christianity.

In particular, Europe recognized others (or otherness) contrast to the Europe Christian countries from these two events. Latin as a common language and common code of Roman law also provided common identity to the European countries along with the common Christian culture. (Note 6) Based on these historical and cultural backgrounds, Pierre Dubois insisted in the 14th century that European counties must have been united to approaching European Confederation through United Christendum of Europe. Aftermath, various thoughts and intents toward European Confederation appeared until the early 20th century. R. Coudenhov Kalergi and A. Briand, a France prime minister, have argued the European confederation in 1929, and EU was developed later on after the World War II. (Note 7)

Some parts of common identity within European countries have disappeared accordingly to the different paths of economic development, the globalization processes as well as the enlargement of the EU since 1980s. Thus, the EU has deployed a common European culture policy to develop the common identity of Europe. For an instance, the Adonnino Committee Report in 1985 provides some alternatives to develop the European identity; (1) overcome the cultural differences among European countries, (2) set up the European identity of people, (3) develop the cultural policy to form common European images. (Note 8)

The Maastricht Treaty in 1992 introduced the common European cultural policy to cooperate the mutual cultural exchange program, and to develop the common European community as Europeanization. According to the Maastricht Treaty, the EU has established series of common cultural policies such as Kaleidoxcope, Ariane and Raphael projects. In the enlargement of the EU in 2000, the new member countries have to keep the "principle of Acquis Communautaire", and to develop "unity in diversity" as a common policy of Europeanization. This Europeanization policy has been proceeded favorably along with these principles in the enlarged EU. It is interesting to see that the common identity of Europe is composed of not only a historical European identity of Christianity, but also the artificially recently made European identity. Many efforts enforced by the European countries toward the common cultural identity provide meaningful policy implications to North East Asian integration. 
C.J.K shared common values and regional identity as a "Northeast Asian cultural community" based on an historical Confucianism until the $19^{\text {th }}$ century. Therefore, re-appreciation of such inherent common cultures would facilitate a new potential for building institutional economic integration in Northeast Asia. The lessons for the Northeast Asian institutional integration from the experiences of the EU are (1) to recognize the historical and cultural commonality among the Northeast Asia, (2) to set up the regional identity by Confucianism as a common culture, (3) to artificially develop "unity in diversity" as a common policy of "Asianization". All of these lessons from the EU could provide necessary conditions for the Northeast Asian institutional integration. In particular, whether the cultural commonality and regional identity could be artificially developed for the Northeast Asia depends on an ability and willingness by each county to do so. This paper is a first attempt to shed light on the values and roles of the Confucian culture as cultural commonality in newly forming institutional integration among C.J.K.

The EU cannot be the best model for Asia because the necessary conditions for regional integration are different between Europe and Asia in terms of commonality of culture, social and economic conditions. However, EU could provide a very important intuition and possible path about how the regional integration works, based on the common cultural values: The Christianity in Europe vs. Confucianism in Asia. This paper does not want to emphasize just the role of the Confucian value, but the common cultural shared value (whatever it is) as a key factor to integrate the NE Asia like in the EU.

\section{Values of Confucianism in an Economic Perspective}

Before examining the relations between Confucian values and regional economic integration, it is necessary to recall the economic development experienced by the Northeast Asian countries since the 1960s. It is because their economic performance seems to be commonly based on Confucian values. Since the 1950s, Japan first, followed in the 1960s by the NIEs (Korea, Taiwan, Hong Kong and Singapore), which were traditionally influenced by Confucian culture, and finally in the 1980s by China have undergone remarkable economic growth (Note 9) The remarkable economic performance of these Confucian-cultured economies makes the Northeast Asia become an emerging economic powerhouse in the world. The academics such as Morishima (1982), Oshima (1984) and Sun (1986) began to examine the positive effects of Confucian culture on Asian economic development since the 1980s. International organizations such as the World Bank (1993) also showed an interest on this issue in the 1990s. A neo Confucianism movement was launched in China, along with the rapid economic growth of China since the 1990s in order to correct the inhumane and unethical problems of the market economic system (Zhang, 1999). All these studies have triggered an ever-increasing interest by the academic community in the relation between Confucianism and economic development.

The positive influence of Confucian culture on the economic development could be represented by Confucian thought regulating people's economic activities with moderate attitude. Confucianism as a norm of behavior has helped people harmonize their ethical norm with economic activities in practice through its educational philosophy such as "discipline yourself and take care of others" (修已安人) and "put into practice what you know" (知行合一). These Confucian thoughts along with the "people centered" political ideology of Confucianism have served as the cultural ethos for the effective governance and stable economic development of East Asian economies since the 1960s. The positive effect of Confucianism on economic performance re-appreciates Confucian culture in the following philosophies of education and politics.

First, the re-establishment of the "for-the-people" ideology (爲民思想) of Confucianism, which differs from the speculative philosophy of the School of Literati "Zhu zi xue", among Confucian values has contributed to the economic development and the economic growth of the Northeast Asian countries. (Note 10) (Moody, 1996). For example, Confucian values such as moral awareness, higher commitment to the people in politics, enthusiasm for education and disciplined behavior seem to play a role as a social capital for economic development in the market economy.

Second, in the traditional Confucian society of China and Korea, qualified scholars both in knowledge and morality were selected as public servants through national examinations to recruit ranked officials. The people had respect for the selected officials who were scholars, and this examination helped prevent bureaucratic corruption, and enhanced the effectiveness of governance. The Confucian political philosophy based on the "for-the-people" and "people-centered" ideologies (民本主義) created a positive impression among the people of the proactive role of the government that can be regarded as a unique socio-political characteristic of Northeast Asian countries. In this sense, Ham (1999) asserted that the government-driven economic development of East Asian countries - Japan, Korea, Taiwan, Hong-Kong and Singapore - in the 1970-80s was partially 
assisted by their Confucian cultural heritage that harmonized the government's responsibility for the people with the people-centered mind of public servants and with the loyalty (忠) to the nation of the people.

Third, Confucianism has been faced with western democracy and Christianity since World War II and it has no longer been able to act as an exclusive ideology allied with the dynastic political power. Confucian political ideology and education philosophy have been chosen by the people as long as they were compatible with the capitalist market economy like Sorman's (1994) observations on sociological transition in East Asian countries since the World War II. Confucian norms no longer controlled the people's daily life, but were transformed into ethical norms since World War II. Confucian values such as thrift, diligence, self-discipline, and emphasis on education have been chosen by the people and transmitted over generations to work as social capital for economic development in this region. The high enthusiasm for education and thrifty supported the formation of human capital required for the industrialization of the countries. (Note 11) All of these Confucian values assume as social capital for economic development and rapid growth in the Confucian countries - Japan, Korea, Taiwan, Hong Kong and Singapore - among many East Asian countries, supporting the rise of the "Confucian Capitalism" argument in 1980s (Note 12) by Ju (2000).

Table 1 shows literacy rate, saving rate, tertiary enrollment, and public spending on education in the Northeast Asian countries, based on the year 2010. The literacy rate representing the enthusiasm for education is $99 \%$ in this region, which is much higher than the world average $89 \%$. The saving rate in the Northeast Asia is $36 \%$, higher than those rates of the EU and North America. The tertiary enrollment and public spending all are higher than South Asian countries and the EU. All of these economic indicators explain the Confucian cultural values prevailing in the Northeast Asia.

Table 1. Literacy rate, saving rate, tertiary enrollment, public spending on education (the year 2010)

\begin{tabular}{ccccc}
\hline & $\begin{array}{c}\text { literacy rate of \% of } \\
\text { people ages 15-24 }\end{array}$ & $\begin{array}{c}\text { Gross saving rate } \% \\
\text { of GDP (average) }\end{array}$ & $\begin{array}{c}\text { Tertiary enrollment } \\
(\% \text {, average) }\end{array}$ & $\begin{array}{c}\text { public spending (\%) on } \\
\text { education of GDP }\end{array}$ \\
\hline $\mathrm{C} \cdot \mathrm{J} \cdot \mathrm{K}$ & $99 \%$ & $36 \%$ & $82 \% * *$ & $13 \% * *$ \\
East Asia & $80 \%$ & $31 \%$ & $41 \%$ & \\
EU & $100 \%$ & $12 \%$ & $60 \%$ & $11 \%$ \\
NAFTA & $92 \%$ & $12 \%$ & $95 \%$ & $13 \%$ \\
world & $89 \%$ & & & \\
\hline
\end{tabular}

*world bank database

**China data is not used due to availability of data. Only data of Japan and Korea are counted on.

\section{Conflicts and Economic Integration among the Northeast Asia}

\subsection{Economic Integration}

Although the institutional economic integration among C.J.K. are not agreed yet, the fast economic growth of China since 1990s led to functional economic integration and the increasing intra-regional export intensity in East Asia especially among China, Japan and Korea (C.J.K) in the last decades. Table 2 shows that intra-regional export intensity increased from 1.28 in 1988 and 1.52 in 1998 to 1.45 in 2008, indicating functional economic integration and the increasing intra-regional export intensity among China, Japan and Korea (C.J.K).

Table 2. Index of export intensity ${ }^{2}$

\begin{tabular}{llllll}
\hline & 1988 & 1998 & 2008 & 2010 & 2012 \\
\hline $\mathrm{C} \cdot \mathrm{J} \cdot \mathrm{K}^{1}$ & 1.28 & 1.52 & 1.45 & 1.19 & 1.16 \\
East Asia & 1.89 & 2.01 & 1.79 & 1.52 & 1.62 \\
EU & 1.47 & 1.42 & 1.79 & 1.91 & 2.01 \\
NAFTA & 1.89 & 2.13 & 2.83 & 2.80 & 3.00 \\
\hline
\end{tabular}

Source : IMF, Direction of Trade Statistics Yearbook. http://www.moea.gov.tw/. 
Note: 1) C.J.K: China, Japan, Korea.

East Asia: ASEAN(5 original members)+3(C.J.K)

EU: 12 for 1988, 15 for 1998-2004, 25 for 2008, 27 for 2012

NAFTA: US, Canada, Mexico

2) Export Intensity: $\frac{x_{i j} / x_{i^{*}}}{x_{* j} / x_{* *}}$, where $\mathrm{x}_{\mathrm{ij}}$ : Exports from $\mathrm{i}$ to $\mathrm{j} . \mathrm{x}_{\mathrm{i} *}$ : Total exports of $\mathrm{i} . \mathrm{x} *_{\mathrm{j}}$ : World exports to j. $\mathrm{x}^{* *}$ : World total exports.

Table 3. Propensity to intra-regional trade

\begin{tabular}{llllll}
\hline & 1988 & 1998 & 2008 & 2010 & 2012 \\
\hline $\mathrm{C} \cdot \mathrm{J} \cdot \mathrm{K}$ & 0.12 & 0.20 & 0.34 & 0.27 & 0.26 \\
East Asia & 0.22 & 0.35 & 0.51 & 0.41 & 0.42 \\
EU & 0.29 & 0.42 & 0.58 & 0.60 & 0.68 \\
NAFTA & 0.14 & 0.23 & 0.34 & 0.32 & 0.38 \\
\hline
\end{tabular}

Source : IMF, Direction of Trade Statistics Yearbook, and World Economic Outlook Database, http://www.moea.gov.tw.

Note: Propensity to Intra-regional Trade, $P_{i}=\frac{X_{i j}}{G D P_{i}} / \frac{M_{j}}{M_{w}}$ Xij: Exports from i to j, Mj: Total Imports of $\mathrm{j}$,

Mw: World Total Imports, GDPi: Total GDP of group I

Although intra-regional trade intensity felt again, it is still higher than the world average 1.0. This fall in the East Asian intra-regional export intensity since 2008 is due to a decreasing world trade caused by world financial crisis and trade diversion of China from Asia to EU and the U.S. It is interesting to note that the East Asian intra-regional export intensity continues to increase to 1.45 in 2008 , but it is much less than those export intensities of the other regions, 1.79 for the EU, 2.83 for the NAFTA. This indicates that there are much social, cultural, political obstacles to the institutional economic integration even though the intra-regional export intensity is increasing.

In Table 3, the propensity to intra-regional trade as an indicator of functional trade integration among C.J.K. has also increased faster than other trading groups between 1988 and 2008. In order to maintain and expand this functional integration and coordinate transnational issues caused by the growing economic interdependency, a region-wide institutional integration scheme is required. This is why institutional economic integration has been stressed in the discussions on building a Northeast Asian economic community since the 1990s. The functional integration is a market oriented economic interdependency among trading partners which have substitutable trades with the other partners. This functional integration through the market trades is a first necessary step forward the institutional integration. Because the effects of trade creation within regional economic community gets greater than the negative effects (trade diversion) of institutional integration when the trade partners are functionally integrated and when intra -regional trade intensity get larger (Sohn, $2012 \mathrm{a}$ ).

Table 4, Table 5 and Table 6 briefly show the numbers of foreign tourists, foreign immigrants and foreign students from the Northeast Asia to China, Japan and Korea, indicating the personal inter-relationship across China, Korea and Japan. 
Table 4. Foreign tourists among China, Japan and Korea (unit, thousands)

\begin{tabular}{cccccccc}
\hline \multirow{4}{*}{ Japan } & Regions & 1998 & 2004 & 2008 & 2009 & 2010 & 2011 \\
& America & 828 & 951 & 1006 & 908 & 945 & 717 \\
& Europe & 577 & 744 & 910 & 820 & 877 & 583 \\
& North East Asia & 2622 & 4338 & 6307 & 4941 & 6654 & 4796 \\
& South Asia & 58 & 84 & 103 & 95 & 105 & 98 \\
\hline \multirow{5}{*}{ China } & America & 948 & 1790 & 2582 & 2491 & 2995 & 3201 \\
& Europe & 1896 & 4097 & 6688 & 5131 & 6366 & 6772 \\
& North East Asia & 60308 & 102394 & 119584 & 117589 & 122889 & 123828 \\
& South Asia & 133 & 514 & 669 & 714 & 871 & 957 \\
\hline \multirow{4}{*}{ Korea } & America & 471 & 611 & 744 & 751 & 814 & 827 \\
& Europe & 401 & 531 & 646 & 646 & 709 & 753 \\
& North East Asia & 2977 & 4253 & 5036 & 6030 & 6769 & 7679 \\
& South Asia & 66 & 95 & 118 & 114 & 135 & 148 \\
\hline
\end{tabular}

*source: International Population Immigrations data base

Table 5. Foreign immigrants among China, Japan, and Korea (unit, persons)

\begin{tabular}{ccccccc}
\hline & Year & 1990 & 1995 & 2000 & 2005 & 2010 \\
China & $\begin{array}{c}\text { Foreign Immigrants } \\
\text { Ratio of Foreign Immigrants to } \\
\text { total population }\end{array}$ & 376361 & 437269 & 508034 & 590252 & 685775 \\
\hline Japan & $\begin{array}{c}\text { Foreign Immigrants } \\
\text { Ratio of Foreign Immigrants to } \\
\text { total population }\end{array}$ & 1075626 & 1362512 & 1686567 & 1998884 & 2176219 \\
\hline Korea & $\begin{array}{c}\text { Foreign Immigrants } \\
\text { Ratio of Foreign Immigrants to } \\
\text { total population }\end{array}$ & 572053 & 584448 & 568071 & 551193 & 534817 \\
& 1.3 & 1.3 & 1.2 & 1.2 & 1.1 \\
\hline
\end{tabular}

*source: United Nations, Department of Economic and Social Affairs, Population Division (2009). Trends in International Migrant Stock: The 2008 Revision (United Nations database, POP/DB/MIG/Stock/Rev.2008).

Table 6. Chinese and Japanese residents and students residing in Korea (unit, persons)

\begin{tabular}{ccccccccc}
\hline \multirow{2}{*}{ country } & $\begin{array}{c}\text { Types of } \\
\text { Residence }\end{array}$ & 2000 & 2004 & 2008 & 2009 & 2010 & 2011 & 2012 \\
\hline \multirow{2}{*}{ China } & Total & 64,822 & 67,409 & 161,734 & 117,563 & 155,252 & 149,208 & 127,289 \\
& Students & 782 & 4,187 & 9,696 & 9,426 & 9,375 & 7,403 & 6,557 \\
\multirow{2}{*}{ Japan } & Total & 5,684 & 6,955 & 4,659 & 4,371 & 4,744 & 5,549 & 5,831 \\
& Students & 170 & 371 & 546 & 602 & 683 & 815 & 775 \\
\hline
\end{tabular}

*Korea National Bureau of Statistics database (KOTIS) 
In Table 4, the numbers of foreign tourists in 1998 from China, Korea and Japan to one of these countries are 2,977,000 for Korea, 60,308,000 for China, and 2,622,000 for Japan. These numbers in 2011 have increased more than 2 times as much as before, 7,679,000 for Korea, 23,828,000 for China, and 4,796,000 for Japan. In Table 5, the numbers of foreign immigrants in 1998 from China, Korea and Japan to one of the Northeast Asian countries are 572,053 for Korea, 376,361 for China, 1,075,626 for Japan. These numbers doubled such as 685,775 for China, and 2,176,219 for Japan except Korea. Table 6 shows the numbers of Chinese and Japanese students residing in Korea. The Chinese and Japanese students were 782 and 170 respectively in 2000, and these numbers in 2012 increased 9 times as much as before. They are 6,557 and 775 for China and Japan. Evidence eventually indicates that the regional integration of East Asian countries are functionally developing in aspects of economic and personal inter-relationship between these countries.

The increasing number of personal inter-relationship between C.J.K can be attributed to cultural similarity, geographical proximity as well as the increasing trade integration between these three countries. It is notable that this growing personal and economic interdependency continuously provides a credible foundation for the institutional integration of the Northeast Asia.

\subsection{Conflicts among North East Asia}

In spite of the growing trend in the functional integration, no institutional integration agreement among the Northeast Asian countries has been concluded due to the emotional conflicts among the Northeast Asian countries. One of the reasons for the emotional conflicts among C.J.K is the strong nationalism in economic as well as political and foreign affair aspects. First, the strong nationalism puts national economic interests over the regional interests. This nationalism arises from a long independent and heterogeneous history with each other over two and a half millennium. Each of China, Japan and Korea is more interested in its own economic interests rather than the whole regional interests, and concerned about the trade imbalance and limitation to independency of policy implementation institutionally endured in the completion of region integration. The nationalism in an aspect of political and foreign affairs also prevails over the regionalism in the Northeast Asia. China wants to maintain economic cooperation with Japan and Korea in line of the China-centered imperialism, while Japan keeps the affiliated union between the U.S. and Japan within the regional integration. Each of C.J.K. wants different types of institutional integration to build up, depending on its political purposes. In 2005, China and Japan did not support the economic cooperation plan by Korean government to set up a regional integration keeping Korea in a hub of the region.

The second reason for the regional conflicts can be found from a variety of differences among C.J.K. such as economic, political, historical and cultural differences. These count on a difference in the economic system, a different gap of the economic development, ideology difference, cultural difference, and historic conflicts including invasions of Japan into China and Korea in the early 20th century. Among them, the difference in the economic system and ideology difference seem to disappear along with the end of the Cold War and the openness of the Chinese economy in 1990s. The difference gap of the economic development is also reduced by dynamic economic growth of Korea and China. Thus, the economic and political reasons are not an obstacle to building up the regional institutional integration anymore. However, cultural and historical conflicts among C.J.K. led to the key emotional barriers of mutual distrust to the regional integration mainly due to the invasion and colonization of Japan over China and Korea. Furthermore, this emotional distrust become even emphasized by each country facing the new international economic order after the end of the Cold War.

A statistical survey using Asia Barometer data of 2006 by Park (2010) shows that these emotional distrusts still prevail over C.J.K. In particular, Chinese and Korean people distrust more against Japanese people than vice versa in the way around. The survey indicates that $44 \%$ out of total samples in China, and $32 \%$ in Korea recognize the common regional identity, but only $21 \%$ out of total samples responds positively in Japan. This result explains a difference in a degree of recognition of the regional identity among C.J.K. and clarifies that the emotional distrust may be due to the difference of recognizing the regional identity among C.J.K. Another study by Park (2011) using survey data from the college students shows that $48 \%$ out of total students respond positively that the regional institutional integration will be necessary in the Northeast Asia. Among them, more than $53 \%$ in Chinese and Korean students said positively, while $70 \%$ out of total students in Japan do not respond positively to the necessity of the regional integration. Considering this difference between the younger generations of Japan and China, Korea, the difference between the older generations experiencing painful historic experiences will be greater than the previous one. The dis-agreement on building-up the regional institutional integration may be deeply rooted from the emotion of the people based on culture and history in C.J.K. Thus, it needs to eliminate the emotional distrust among neighboring countries, and to develop regional identity and cultural commonality as necessary condition for the institutional integration. Re-appreciation of 
such inherent common cultures would facilitate a new potential for building institutional economic integration in Northeast Asia.

\section{Roles of Confucianism for the Institutional Economic Integration}

\subsection{Regional Identity}

The Confucian cultural commonality and its values can provide an opportunity for the Northeast Asian countries to develop a regional identity, which is an informal determinants of the spontaneity and durability of an economic community. This is very important role in a discussion of the regional economic community. The regional identity in this paper means a common social- and cultural- basis of understanding that promotes mutual trust and unity among Northeast Asian countries. Regional identity will exert an integrating force to put Northeast Asian countries into a long-lasting and strongly-tied community. Regional economic integration without common regional identity will produce neither regional homogeneity nor spontaneous integrating motif. Each country without regional identity will join the economic community only to the extent of furthering their own economic interests. No economic motif, no economic community has incentive for ever-existence. Thus, traditional values of Confucian culture inherited in Northeast Asian countries must be re-appreciated in providing a cultural base for securing regional identity as a sufficient condition for Northeast Asian economic integration. Therefore, if an institutional economic integration advances in tandem with the regional identity based on Confucian values, C.J.K in Northeast Asia can easily approach a regional economic community endowed not only with a large market but also with socio-cultural solidarity. Confucian common values in C.J.K countries will narrow down the differences in the thought-way arising from the different modernization processes among these countries, thereby facilitating the institutional integration in this region. The movement toward a single economic community based on the common Confucian culture provides many politico-economic implications for the region as in the followings.

If a regional economic community is built on the common foundation of a Confucian culture, Northeast Asian values will be shared as a common recognition system of this community. The consequent development of Northeast Asian values will contribute to the equally dynamic development of the global community by preventing cultural imperialism resulting from a hegemonic superpower. The development of Northeast Asian values can contribute to attaining a balance of cultural power between the West and the East when the Western hegemonic system dominates. The pursuit of Northeast Asian values as a regional identity will be of significance in regional integration because they will provide a foundation for regional solidarity and cooperation. Actually, since the launch of the Asia-Europe Meeting (ASEM) in 1996 as an inter-regional dialogue channel between the two continental groups, ASEAN +3 members have been strengthening their unity to enhance their status relative to that of Europe. (Hanggi, 1999). They began to focus more on the development of East Asian values to prevent East Asia from being absorbed into the European cultural community. The institutional economic community based on common Confucian values will be appreciated by securing the Northeast Asian identity within the global economic system and by ensuring the cultural diversity in the world system.

\subsection{Social Capital}

The second role of Confucian culture associated with the institutional economic community is the formation of social capital of the region. According to modern economic theory, a country's economic growth depends on input of production factors such as capital input. The formation of capital depends on the saving rate of the country, which, in turn, depends on the behavioral culture such as custom of thrift and frugality. The efficiency of the same amount of capital input depends on the formation of social capital such as mutual trust, social ethics and education. Thus, the economic performance of East Asian countries has been influenced by the regional social capital originating from the traditional Confucian culture. (Note 13)

Therefore, the development of common Confucian cultural values in Northeast Asian countries could be understood as a path of enlarging the social capital of the region. Furthermore, some elements of this social capital, such as Chinese characters, are able to act to some extent as regional public goods facilitating the regional integration by transnational usage in the region especially among C.J.K. Thus, the Northeast Asian economic community will fully deserve its own characteristics, compared to the other communities elsewhere. The economic community of C.J.K. follows the trend of globalization through the market system, while maintaining its regional Confucian characteristics at a same time.

\subsection{Solution to the Immorality of the Market Economic System}

Confucian values as cultural commonality in Northeast Asia can serve as a morality foundation against the inhumane and immoral aspects of the market economic system. The Confucian ethical values can prevent the 
corruption of capitalism and maintain the sustainable development of a capitalist market economic system. The spirit of Confucian ethical self-discipline is necessary as a remedy for the breakdown of traditional social norms such as the de-gradation of moral norms, unlimited individual desire and overly fierce competition in the post-industrial society. For instance, Confucian values such as humanity, righteousness, moderation of attitude (禮, overcome individual intrinsic desire), loyalty and filial piety as well as the philosophy of the negative version of the Golden Rule (絜矩之道: Don't ask to others what you don't want to do), can serve as a moral and educational compass for repairing the ethical norms damaged by the market economic system.

Confucian economic community means grafting Confucian moral ethics to market-oriented economic integration. Therefore, this kind of economic integration will be able to contribute to protecting the market economy from moral corruption and supporting sustainable development. Furthermore, the anthropocentric and education-oriented philosophies of Confucianism can serve as a new growth engine of the knowledge-based economy in the 21 st century as insisted by Ahn (2000). In the globalization of economic activities, it is easy to lose humanity and moral ethos due to the unlimited global competition. In the course of economic globalization, a natural tendency has arisen to draw attention to technology and competition while disregarding the humane and moral aspects. The introduction of Confucian philosophy stressing moral ethics will compensate for the weakness of globalization and will meet the cultural needs of the knowledge-based society. It is also necessary to appreciate the Confucian philosophy of "harmony between nature and human"(天人合一) as a new initiative for the development of a world economy which requires the "environmentally friendly" economic growth.

\section{Conclusion and Policy Implications}

This study has examined the culture commonality of Northeast Asian countries based on Confucian values, and their relations to institutional economic integration. This study demonstrates that Confucian values inherent in the Northeast Asian countries have served as the cultural ethos for the rapid economic growth of this region since the 1960s and will be able to form the foundation of Northeast Asian values in the future. Therefore, re-appreciation of these cultural values as a necessary condition for regional integration will catalyze the stagnated discussions about economic integration and extend its inter-weaving connection role for intra-regional transaction among C.J.K countries.

Despite the economic significance of Confucian values for institutional economic integration, a regional integration approach based on Confucian values has not been appreciated until recently, primarily because most people in this region have been skeptical about the existence of Confucian values as a cultural commonality. The influence of Confucianism in the daily life of citizens of C.J.K has been greatly damaged by the influx of Western culture since the beginning of the $20^{\text {th }}$ century, ideological war, and the invasion of Japan into China and Korea. Therefore, the Confucian values, in this paper, are discussed as cultural values operating in a traditional context. Furthermore, in the face of recent globalization, conventional Confucian values do not exert a dominant effect on actual life but remain latent in the history of each country. They are even on the verge of disappearance due to their rejection to the periphery of the neo-liberal market economic order (Note 14).

In order to build a regional economic community among C.J.K based on traditional culture commonality, Confucian values should be re-appreciated from their dormant stage, along with the new regionalism movement in the $21^{\text {st }}$ century. They should be re-identified and re-interpreted in order to be compatibly harmonized with the current market economic system. All efforts should be made to develop them into a common culture value of C.J.K countries.

In order to focus on explaining the positive roles of Confucian values on the regional integration, this paper ignores their negative sides in main text since they may obscure the main focus. The discussion of the negative effects of the Confucian values is beyond the scope of the paper. However, there are negative sides of Confucian values. Even the positive values of Confucianism could be reverted into the negative ones in some cases. For instance, Confucian values such as loyalty and filial piety can serve as a moral and educational compass for repairing the ethical norms damaged by the market economic system. However, these values may also make people behave irrational, causing social and economic inefficiency. Resources may be not re-distributed according to the economic efficiency, but to the social hierarchy order. This eventually prevent the economic development of Asian countries with Confucian cultures in commonality.

\section{References}

Ahn, C. (2000). Economic Development Model for East Asia in $21^{\text {st }}$ Century, Korea Chamber of Commerce and Industry, Economic Research Book Series, No.341.

Confucius. The Analects. 
Goyasu N, (2005). East Asia, Great East Asia: Modern Japanese Orientalism (Korean). History and Critics Co. Seoul.

Ham, J. (1999). Politics of the Arguments on Asian Value and Its Implications. In S. H. Lee, et al (Eds.), Asian Value (pp. 207-208). Tradition and Modern Co.

Hanggi, H. (1999). ASEM and the construction of the new Triad. Journal of the Asia Pacific Economy, 4(1), 56-80. http://dx.doi.org/10.1080/13547869908724670

Ju, S. -H. (2000). Economic Development Theory in East Asia and Confucian Market Economy. The Comparative Economic Review. The Korea Association of Comparative Economics, 7(2), 308-328.

Kahn, H. (1979). World Economic Development: 1979 and Beyond. London: Croom Helm.

Mayer, C., Franz, C., \& Palmowski, J. (2004). European Identity and the EU - the Ties that Bind the people of Europe. Journal of Common Market Studies, 42(3), 576-596. http://dx.doi.org/10.1111/j.0021-9886.2004. 00519.x

Moody Jr., P. R. (1996). Asian Values. Journal of International Affairs, 50(1), 192-210.

Morishima, M. (1982). Why has Japan 'Succeeded'? Western Technology and the Japanese Ethos. Cambridge: Cambridge Univ. Press. http://dx.doi.org/10.1017/CBO9780511582455

Na, J. S., Kwon, Y. H., \& Lee, J. W. (2009). Formation of Regional Identity in East Asian Community. In Northeast Asian History Foundation (Ed.), Current Issues and prospects for East Asian Community (pp. 181-378). Northeast Asian History Foundation.

Oshima, H. (1984). Economic Growth in Monsoon Asia: A Comparative Survey. Tokyo: Tokyo University Press.

Park, K. S. (2010). Social Capital of the three Northeast Asian Countries - China, Japan and Korea - and the Formation of Regional Community. Research Paper reported to the POSCO Chung-am Foundation, 74-79.

Park, J. H. (2010). The Regionalism of North East Asia: Model Expansion and Its Application. The Korean Comparative Economic Review, 18(2), 51-91.

Peter, B. (2002). What's so European?, Legitimacy between Institution and Identity. European Journal of Social Theory, 5(4), 467-481. http://dx.doi.org/10.1177/136843102760513866

Putnam, R. (1993). The Prosperous Community: Social Capital and Public Life. The American Prospect, 4(3), $35-42$.

Ryu, S. (2005). Confucian Ethics and the Spirit of Capitalism in Korea: Centered on Filial Piety. Korean Sociology, 39(6), 3-21.

Smith, A. D. (1992). National Identity and the Idea of European Unity. International Affairs, 68(1), 55-76;

Sohn, B. H. (2009). The Cultural Background of Regional Integration in Europe and in East Asia. Journal of Contemporary European Studies, 27(2), 313-339.

Sohn, B. H. (2012a). Characteristics of Intra-regional Trade Integration among Korea, China, and Japan and Its Implications for C.J.K FTA. Journal of International Trade and Industry Studies, 17(3), 39-45.

Sohn, B. H. (2012b). C.J.K Economic Integration through Common Cultural Denominator: Centered on the Traditional Confucian Values". KUKJE KYUNGJE YONGU (Korea Journal of International Economics), $18(4), 1-24$.

Sorman, G. (1995). Le Capital, Suite et Fin (p. 256, Translated in Korean by Kim Chung Eun.) Korea Economic Daily Co.

Swann, D. (2002). The Economics of Europe from Common Market to European Union (New ed.). London: Penguin Books.

Sun, L. T. (1986). Confucianism and Economic Order of Taiwan. International Review of economics and Ethics, 1(2), 3-15.

Toynbee, A. J. (1972). A study of History. Oxford University Press: Abridgement by D. C. Somervell.

Tu, W. -M. (Ed.). (1996). Confucian Traditions in East Asian Modernity: Moral Education and Economic Culture in Japan and the Four Mini-Dragons. Cambridge: Harvard University Press.

Vogel, E. (1979). Japan as Number One. Cambridge: Harvard University Press. http://dx.doi.org/10.4159/ harvard.9780674366299 
Wada Haruki. (2004). Touhoku Asia Kyoudou No Ie (Common house of Northeast Asia). Heibonsha Co., Korean edition, Seoul: Il Jo Gak Co.

World Bank. (1993). The East Asian Miracle: Economic Growth and Public Policy. Washington, D.C.

Yang, S. (2000). Future Tasks for Cultural Reconstruction in East Asia. The Comparative Economic Review, The Korea Association of Comparative Economics, 8(1), 48-61.

Zhang, J. (1999). Some efforts of the Neo-Confucian and the Universal Ethics. In Proceedings of International Conference on "Universal Ethics and Asian Values". Korean National Commission for UNESCO, Seoul.

\section{Notes}

Note 1. The concept of economic community, in this paper, means an integrated region characterized by institutional or functional economic integration where close economic and socio-cultural interdependence among member countries has been realized.

Note 2. In this paper, the term of "Northeast Asian countries" refers to Confucian countries in the Northeast Asian region, including China (mainland, Taiwan, Hong Kong), Korea, and Japan.

Note 3. Societies with a short-term orientation generally have a strong concern with establishing the absolute Truth. They are normative in their thinking. They exhibit great respect for traditions, a relatively small propensity to save for the future, and a focus on achieving quick results. In societies with a long-term orientation, people believe that truth depends very much on situation, context and time. They show an ability to adapt traditions to changed conditions, a strong propensity to save and invest, thriftiness, and perseverance in achieving results.

Note 4. The notion of Northeast Asian values can be construed as the same meaning as Asian values that found across the East Asia especially in a sense of collectivism and collective interests take preference over individualism and personal interests. However, this paper differentiates it from Asian values because the former reflects mainly Confucian values rooted profoundly in Northeast Asia while the latter used to be construed as traditional values stem from not only Confucianism but also other cultural systems in East Asia.

Note 5. Anthony D. Smith, (1992). "National Identity and the Idea of European Unity," International Affairs, 68(1), pp. 55-76; Burgess J. Peter, (2002). "What's so European?, Legitimacy between Institution and Identity," European Journal of Social Theory, 5(4), pp. 467-481;. Arnold J. Toynbee, (1972). A Study of History, Oxford: Oxford University Press.

Note 6. Byeong-hae. Sohn, (2009), "The Cultural Background of Regional Integration in Europe and in East Asia", Journal of Contemporary European Studies, 27(2), pp313-339.

Note 7. Dennis Swann, the Economics of Europe from Common Market to European Union, New Edition ( London: Penguin Books, 2000), pp. 1-2.

Note 8. Franz C. Mayer and Jan Palmowski, "European Identity and the EU - the Ties that Bind the people of Europe," Journal of Common Market Studies, Vol. 42, No. 3 (Sept. 2004), p. 576.

Note 9. The annual average economic growth rate of the five Confucian countries (Korea, Japan, Hong Kong, Taiwan, and Singapore) was $9.7 \%$ in the $1960 \mathrm{~s}, 8.5 \%$ in the $1970 \mathrm{~s}$, and $7.0 \%$ in the $1980 \mathrm{~s}$, while that of the middle income countries was $6.1 \%, 5.5 \%$, and $2.9 \%$ respectively, and that of the high income countries was $5.1 \%, 3.2 \%$, and 3.0\% respectively (World Bank, World Development Report, and Taiwan Statistical Data Book, every year).

Note 10. When it comes to "the School of the Literati” (朱子學), namely Neo-Confucianism, Confucian thought has become a restraint on people's economic activities. The educational philosophy of "self-discipline" (修己) was greatly emphasized as a moral standard over economic activities. In this neo-Confucian thought, people's economic activities, including private profit-seeking activities, had to be restrained. In the same context, Confucian thought emphasized the superiority of moral values over material ones. Public interest (公) and social justice (義) were cherished in priority, while self-interest(私) and private profit(利) were disregarded. These thoughts led to the underestimation of commercial business, which pursues private interest, and the consequent descent of merchants in the social hierarchical system. For this reason, Confucian culture was regarded as a socio-cultural obstacle that prevents the development of capitalist market economic system.

Note 11. Ryu(2005) argued that the concept of filial piety (孝) in Confucian culture encouraged the development of capitalism in Korea. For example, strong investment in education for the next generations, as a means of 
realizing fathers' dream through sons' success in life(:a sort of filial piety), resulted in accumulating human capital required for economic development.

Note 12. The initial stage of the Confucian Capitalism discourse was led by Kahn (1979), Vogel (1979), Morishima (1982), and Tu (1996). The discourse of Confucian Capitalism can be largely divided into two perspectives: the function of Confucianism in the business management structure and the role of Confucianism in the national economic development. The former tries to identify features of East Asian business culture with regard to the strong blood relationship within families. The latter sheds light on the characteristic of East Asian capitalism with regard to government-led economic policy and the overall performance of the national economy.

Note 13. According to Putnam,R.(1993), Social capital refers to social value or social norm that enhances the social cooperation and its efficiency. In the case of Northeast Asia, the social capital has been developed more than in other regions thanks to the Confucian culture that stresses the social relations with social trust and social tolerance.

According to the Analects, Chapter XII-7, Confucius indicated "trust" as the most important value for politics among three important constituents of political object: foods, army and trust. This Confucian political philosophy has influenced the formation of social capital such as social trust in the traditional Confucian societies of Northeast Asian countries.

Note 14. According to the recent surveys of Park (2010) on East Asian regional values and social capital, there are still alive some vestiges of Confucian traditions such as the mode of thought based on blood relations and family values, although general traditional Confucian culture has largely disappeared in C.J.K.

\section{Copyrights}

Copyright for this article is retained by the author(s), with first publication rights granted to the journal.

This is an open-access article distributed under the terms and conditions of the Creative Commons Attribution license (http://creativecommons.org/licenses/by/3.0/). 